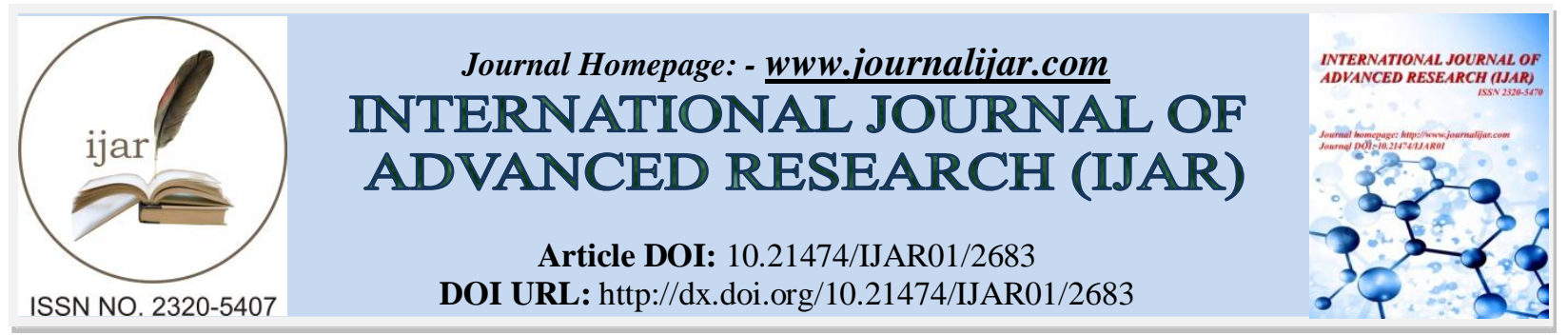

RESEARCH ARTICLE

\title{
CONTRIBUTION OF RAJA RAM MOHAN ROY'S TO LITERATURE AND JOURNALISM.
}

Dr. P. Thangamuthu M.A. M.Phil. Ph.D.

Assistant Professor Research Department of History PTMTM. College Kamuthi Ramnad District Tamilnadu.

\section{Manuscript Info}

Manuscript History

Received: 31 October 2016

Final Accepted: 01 December 2016

Published: December 2016

\section{Key words:-}

Dark period of Indian History - Freedom of the Presspublished newspapers in English, Bengali and Persianthe newspapers as an instrument for diffusing intellectual light- chronological list of books in Bengali language - Ram Mohan's important English works Modernizing India through changes in its educational system

\section{Abstract}

Raja Ram Mohan was a great champion of the freedom of the Press. His efforts to liberate the Press were made with the aim of education Indians about the affairs of the nation in their true perspective. $\mathrm{He}$ himself published newspapers in English, Bengali and Persian for the purpose of creating mass consciousness as a veritable check against the British authoritarianism. Besides being a great social reformer Ram Mohan also made a valuable contribution to Bengali literature and he is regarded as the father of Bengali prose. He was the first to realize the value of the newspapers as an instrument for diffusing intellectual light. Everywhere there reined despair and dejection. He believed that any progress of his country could be possible only when it was freed from its superstitious and all forms of ignorance. Evidently, the rise of Raja Rammohan Roy may be regarded as a historic break with the past of India. He has been one of those persons at the time who fully understood the importance of the modern age. His advent has been in a period when the social and political conditions in the country were feudal, both in kind and spirit. It is extremely difficult to evaluate the multifarious activities of a great man like Raja Rammohan Roy. Hence, a humble attempt is made to evaluate the contribution made by Raja Rammohan Roy in the domain of modernizing India through changes in its educational system. It is devoted to trace the role played by ram Mohan in literature and journalism in Bengal.

\section{Objectives:-}

- To analyze the importance of literature and journalism in India through changes in its English Educational System.

- To know about the Realize the value of the newspapers as an instrument for diffusing intellectual light.

- To explain about Raja ram Mohan Roy's contribution to literature and journalism.

How? Ram Mohan's Role as a Journalist.

\section{Hypothesis:-}

To study growth of Literature and Journalism in India.

- To study the various linguistic literatures and journalism and press media system in India.

- To equalize and freedom of press opportunities irrespective of caste, colour, and creed of the learners. 


\section{Methodology:-}

It is descriptive and analytical methodology of the research. This article is based on the primary and secondary sources collected from magazines, newspapers, Research articles, Research journals, books of various authors and other published materials.

Copy Right, IJAR, 2016,. All rights reserved.

\section{Introduction:-}

Rammohan was a great champion of the freedom of the Press. His efforts to liberate the Press were made with the aim of education Indians about the affairs of the nation in their true perspective. He himself published newspapers in English, Bengali and Persian for the purpose of creating mass consciousness as a veritable check against the British authoritarianism. Besides being a great social reformer Ram Mohan also made a valuable contribution to Bengali literature and he is regarded as the father of Bengali prose. He was the first to realize the value of the newspapers as an instrument for diffusing intellectual light. His earliest books on Bengali prose were Vedanta Grantha and Vedanta - Saar which were published in 1815 and 1816 respectively. Following is the chronological list of his works in Bengali;

1. Vedanta - Grantha, 1815; It was a commentary on the Vedanta - sutra.

2. Vedanta - Sar, 1815; It was an abridge and simpler version of Vedanta Grantha.

3. Talabakaropanisat or Kenopanisat, 1816; It was a Bengali translation based on Samkara - Bhasya.

4. Isopanisat, 1816; It was also a Bengali translation based on Samkara - Bhasya.

5. Bhattacaryyayer sahit Vicar, 1817; Sastric disputation with Bhattacaryya on idol - worship.

6. Kathopanisat, 1817; Bengali translation based on Samkara Bhasya.

7. Mandukyopanisat, 1817; Bengali translation based on Samkara Bhasya.

8. Gosvamir Sahit Vicar, 1818; It was a disputation with Gosvami on monotheism.

9. Sahamaran Visaye Pravartak O Nivartak Samvad, 1818: "A Conference between an Advocate for and opponent of the Practice of Burning Widows Alive."

10. Gayatri Artha, 1818: It was an explanation of the Gayatri mantra.

11. Mundakopanisat, 1819: It was a Bengali translation based on Samkara Bhasya.

12. Atmanatmaviveka, !819: Samkaracarya's text along with Bengali translation.

13. Sahamaraner Visay Pravartak O Nivartaker Dvitiya Samvad, 1819: 'A Second Conference between an Advocate for and an Opponent of the Practice of Burning Widows Alive.' In this polemical tract Ram Mohan gives his rejoinder to Kasinath Tarkavagi's Vidhayak Nisedher Samvad, an apology for Sati.

14. Kavitakarer Sahit Vicar, 1820; A Sastric disputation with Kavitakar.

15. Subrahmanya Sastri Sahit Vicar, 1820: Sastric disputation with Subrahmanya Sastri.

16. Brahman Sevadhi: Brahman O Misinari Samvad (numbers 1, 2 and 3 ), 1821: In this work Ram Mohan refutes the attacks of the Christian Missionaries upon Hinduism.

17. Cari Prasner Uttar, 1822: Answers to four questions put by an advocate or orthodox Hinduism.

18. Prathanapatra, 1823: The English version was entitled Humble Suggestions to his countrymen who believe in One True God.

19. Padri O Sisya Samvad, 1821: Written in the form of an imaginary conversation between a Trinitarian Missionary and three Chinese converts, this polemical tract exposes the fallacies of Trinitarianism.

20. Gurupaduka, 1823: The text a rejoinder to a pseudonymous polemic has not yet been traced.

21. Pathyapradan 1823: Medicine for the sick, offered by one who laments his inability to perform all righteousness.

22. Brahmanistha Grhasther Laksman, 1826: This short tract analyses the characteristics of a householder faithful to Brahman.

23. Kayasther sahit Madyapan Visayak Vicar, 1826: Sastric disputation with a kayastha on drinking Wine.

24. Vajrasuci 1827: Sanskrit text along with the Bengali translation of prathma - nirnaya of Vajrasuci Upanisat ( a Mahayana Buddhist work ) which shows that in the final analysis, Brahmana means a believer in Brahman.

25. Gayatrya paramopasanavidhanam, 1827: An exposition both in Bengali and in Sanskrit of the mode of divine worship through the chanting of the Gayatri.

26. Brahapasana, 1828: Another tract on the mode of divine worship.

27. Brahmasangit, 1828: A book of Bengali devotional hymns.

28. Anusthan, 1829: A catechism that expounds Ram Mohan's doctrine of divine worship.

29. Sahamaran Visay, 1829: Ram Mohan's last polemic on Sati. 
30. Kshudra Patri (exact date of publication is not known )

31. Gaudiya Vyakaran, 1833: It was a work on Bengali grammar.

Gaudiya Vyakaran is the last work of Ram Mohan. Before this he wrote a book of grammar in English entitled 'Bengali Grammar in the English Language'. Gaudiya Vyakaran was written by him for the School Book Society. The language of this book is very simple and it can well be called modern. Such simple style was unknown in those days of 1830's.

The Raja was conversant with many languages and prominent among them are: Sanskrit, Arabic, Persian, Hindustani, Bengali, English, Hebrew, Greek, Latin and French. He made the best use of English language to communicate his ideas. But before doing that he made a deep study of English in the twenty - second year of his life.

In a letter to Ram Mohan, Jeremy Bentham, the celebrated English philosopher, wrote. Your works are made known to me by a book, in which I read a style, which but for the name of a Hindu, I should certainly have ascribed to the pen of a superiorly educated and instructed Englishman. In the same letter Bentham compared Ram Mohan with James Mill (author of the History of India) in the matter of style. A look at the list of Ram Mohan's important English works will convince us about his high attainment in English language and literature.

1 Translation of an Abridgement of the Vedant, 1816: the most celebrated and revered work of Brahminical Theology: establishing the Unity of the Supreme Being; and that he alone is the object of Propitiation and Worship.

2 Translation of Cena ( kena ) Upanished, 1816; one of the chapters of the Samad Veda: according to the gloss of the celebrated Shankaracharys; establishing the Unity and the Sole Omnipotence of the supreme being: and that his Worship alone can lead to Eternal Beatitude.

3 Translation of the Ishopanishad, 1816; one of the chapters of the Yajoor Ved; according to the commentary of the celebrated Shankaracharya; establishing the Unity and incomprehensibility of the Supreme Being and that his Worship alone can lead to eternal Beatitude.

4 A Defence of Hindoo theism, 1817; in reply to the Attack of an advocate for Idolatry in Madras.

5 A Second Defense, 1817; of the Monotheistic System of the Vedas in reply to an apology for the present state of Hindu worship.

6 Translation of A Conference, 1818: between an advocate for, and an opponent of, The practice of Burning Widows alive from the original Bangla.

7 Translation of the Moonduk Opunishud, 1819; of the Uthurvu - Ved, according to the gloss of the celebrated Shunkura - Charyu.

8 Translation of the Kut $\mathrm{H}$-Upanishad, 1819; of the Ujoor - Ved, according to the gloss of the celebrated sunkuracharya.

9 An apology for the Pursuit of final Beatitude, (1820): independently of Brahmunical Observances.

10 A Second Conferences between an advocate for, and an opponent of the Practise of Burning Widows Alive. 1820.

11 The Precepts of Jesus, 1820: The Guide to Peace and Happiness: extracted from the books of the New Testament ascribed to the four Evangelists. With translation into sungscrit and Bengali, Calcutta: printed at the Baptist Mission Press, Circular Road.

12 An Appeal to the Christian public in Defenses of the; Precepts of Jesus:' 1820: by a friend to Truth printed at Calcutta.

13 The Brahmunical Magazine, or the Missionary and the Brahmum, 1821 beings a Vindication of the Hindu religion against the attacks of Christian Missionaries, I, II, and III.

14 Second Appeal to the Christian Public, (1821) in Defense to the: Precepts O Jesus.

15 Brief Remarks regarding Modern Encroachments on the Ancient Rights O Female, 1822; according to the Hindu Law Inheritance.

16 The Brahmunical Magazine, 1833: or the Missionary and the Brahma, No, 4.

17 Umble suggestions, 1833; to his countrymen who believe in the One True God.

18 A Vindication of the Incarnation of the Deity, 1833; as the common basis of Hinduism and Christianity against the Schismatic attacks of R. Tyles, Esq, MA by Ram Doss Printed by S. Smith and Co,Hurkaru Press, Calcutta.

19 Petitions Against the press Regulations, 1833; (a) Memorial to the Supreme Court (b) Appeal to the king in Council. 
20 A letter on English Education, 1833; to His Excellency the Rt. Hon. Lord Amherst the Governor- General in Council

21 Final Appeal to the Christian Public in Defense the Precepts O Jesus" 1823: Printed at the Unitarian Press Dhurmtollah, Calcutta.

22 A Dialogue 1823; between a Missionary and three Chinese Converts.

23 A letter to Rev. Henry, Ware on the Prospects of Christianity in India, 1824.

24 Translation of Sanskrit Tract on different Modes of Worship, 1825.

25 Bengali Grammar, 1826; in the English language Printed at the Unitarian Press, Dhurmtollah Calcutta

26 A translation of a Sanskrit Tract 1827; including the Divine worship esteemed by those who believe in the relegation of the Vedas as most appropriate to the nature of the Supreme Being.

27 Answer an indoo, 1828; to the question, why do you frequent a Unitarian place of worship place of worship instead of the numerously attended established Churches?

28 Petition to Government against Regulation III, of 1828 for the Resumption o Lakheraj Lands, 1828.

29 The Universal Religion, 1829; Religious Instruction founded on Sacred Authorities.

30 The Trust - Deed, 1830; of the Brahmo Samaj.

31 Abstract of the arguments regarding The Burning o Widows, 1830; considered as a religious right.

32 Essays on the Rights of indoo over Ancestral Property, 1830; according to the Law of Bengal.

33 Letters on the indoo Law of Inheritance, 1830.

34 Address to Lord William Bentinck, 1830 Governor-General of India, upon the passing of the Act for the Abolition of the Suttee.

35 Counter-Petition to the House of Commons to the Memorial of the Advocates of the Suttee, 1831.

36 The English Works of Raja Ram Mohan Roy" 1885; edited (with an introduction ) by Jogendra Chunder Ghose, M.A, B.L, compiled and published by Eshan Chunder Bose, Vol, I Oriental Press, Bhowanipore, Calcutta.

37 The English works of Raja Ram Mohan Roy" 1887; edited (with an introduction) by Jogendra Chunder Ghose, M.A., B.L., compiled and published by Eshan Chunder Bose Vol II Aruna press, Bhowanipore,Calcutta.

Apart from the above mentioned publications there are works printed and published from England and there are specific book published by the British Museum in London such as Tuh at -ul-Muwahhadin.

Since Ram Mohan had his early education in Hindi knowing cities like patna and Varanasi he learnt the language well. He wrote simple and lucid Hindi and his command over the language was a matter of wonder. His high attainment in Hindi language is testified to by the eminent critic Pandit HazariPrasad Dwivedi, who has said that the Hindu of Ram Mohan is not a Bengali Hindi" It is grammatically correct. According to Divedi if there is any error it was not on account of Ram Mohan 's fault. It is so because he followed the style in vogue among the pandit Mandalees' of that place. It is worthy of note that Ram Mohan Roy wrote Hindi prose in Devanagiri script voluntarily whereas the teachers of Fort William were compelled to adopt the script because of several considerations.

Ram Mohan published Hindi translation of Vedanta Sutra in 1815. In the following year he published another small book dealing with Shastrarth: That took place with Subrahmanya Shastri, the famous Pandit of Kashi. The Shastrarth had been held at the residence of one Bihari Lal Chaubey in Calcutta. Soon Ram Mohan established himself as the third leading writer in Hindi in Devanagiri script. The other two were Lalluji andSadal Mishra whose works were published in 1801. In the opinion of Hazari Prasad Dwivedi these three writers were the pioneers of Hindi prose so in the horizon of Bengali literature Ram Mohan's name has been immortalized by dint of his enormous productions. He is hailed by the latter day critics and authors as the father of Bengali prose. Though there are prose's writing even prior to Ram Mohan his specific contributions created a great transformation in the literary genres of the Bengali language and also a social change in the society.

\section{Ram Mohan's Role as a Journalist:-}

Ram Mohan played an important role in promoting Indian Journalism. He was the first Indian to realize the value of the newspaper as an instrument for diffusing intellectual light. The upsurge that came into the wake of the manifold reform movement initiated by Ram Mohan underlined the need for a liberal Press. The origin and the development of the press in Bengal can be traced to this important need.

The first liberal paper to be published was the Bengali Gazette Bengali weekly started in Calcutta in 1816 by the enthusiastic members of the Ram Mohan's Atmiya Sabha. The newspaper continued to be published till 1820. The 
Serampore Christian Mission started another Bengali weekly, The Samachar Darpan in 1817, and also published an English journal named the Friend o India. The first liberal newspaper in English, The Calcutta Journal, was brought out by James Silk Buckingham in October, 1818.

The Sambad Kaumudi a Bengali weekly was started in December, 1821 by Tarachand Dutta andBhabani Charan Bandyopadhyaya. Bhabani Charanresigned from the editorship of this paper in December 1821, Ram Mohan took charge of it. The Sambad Kaumudi was intended for the common people. Ram Mohan used the new Bengali prose style for the man in the street. The first issue of Sambad Kaumudi edited by Ram Mohan appeared on December 4, 1821.

The Sambad Kaumudi dealt with subjects of public interest. For example, it appealed to the government for establishing a school for free education of the children of the poor. Another issue contained an appeal to parents for giving their children instruction in the grammar of their own languages before imposing upon them the study of foreign languages. An article contained the description of the miserable condition of the Hindus suffering from caste prejudices. Another issue contained an advice to the Hindus to become tradesman rather than mere clerks. The paper also appealed to the government to establish trial by jury in the Zila and Provincial Courts.

In Apirl 1822, Ram Mohan started Persian Weekly named the Mirat-ul-akhbar (Mirror of News). Through this paper he tried to communicate his political and social views to the educated elite according to their needs. The Mirat-ul-Akhbar happened to be the first journal in Persian language to be published in India.

In the Prospectus of the Mirat-ul-Akhbar, published in the first issue of the weekly, Ram Mohan wrote that the object of the paper was not to shower praises upon its promoters or his well-wishers or to scandalize anybody. On the contrary, it aimed at reaching the truth, In its second issue Ram Mohan published his article on the British Constitution. In 1822, Ram Mohan wrote an editorial about the trial protesting against the cruel treatment meted out to one Pratap Narayan Das who had succumbed to the injuries caused by whipping ordered by John Hayes, the Judge of Camilla. As a result of this Hayes was tried by the Supreme Court in April that year. Ram Mohan's editorial was translated into English, and published in the Calcutta Journal of May 14, 1822 by its editor, James Silk Buckingham who was a great friend of Ram Mohan.

In all his publications Ram Mohan emphasized the important of subjects having educational value, besides those on politics and theology. During $1821-24$ he published in the Mirat-ul-Akhbar several articles on scientific subjects like "Echo in Acoustics" Properties of the Magnet", "Behaviour of fishes" Description of a Baloon, etc. His persistent Advocacy for the introduction of scientific education bore fruit long after his death.

But there was a section of journalists which was opposed to the liberal attitude of Sambad Kaumudi. This was the group of the orthodox Hindus who started the Samachar Chandrika in March, 1822, counteract the zeal for reform of the Sambad Kaumudi. But that did not cut much ice.

The Persian editorial of the Mirat-ul-Akhbar written by Ram Mohan were translated into English and were published in the Calcutta Journal, edited by James Silk Buckingham. In this editorial Ram Mohan revealed his great learning and deep knowledge of the political affairs of his time.

Ram Mohan's editorial criticism of popular Christian faith, English foreign policy and of the British insolence on public roads towards the common people appeared too venomous for the British administration in India to swallow.

Soon the acting Governor- General came down with a heavy hand for the suppression of the liberty of the Press, and promulgated a new Press Ordinance, drastically curtailing free expression of opinion through the press. Immediately after the enactment of the Ordinance, Ram Mohan closed down the Mirat-ul-Akhbar as a mark of protest. In the last issue of his paper, he declared his inability to go on publishing under" what he considered were degrading conditions and he lamented that he one of the most humble of men, should be no longer able to contribute towards the intellectual improvement of his countrymen.

After suspension of the Mirat-ul-Akhbar in 1823 Ram Mohan became connected with several other periodicals, and continued his relentless crusades against irrationalism and suppression of freedom of the Press. In May 1829 English weekly, Bengal Herald was started by R.M. Martin in collaboration with Ram Mohan and Dwarkanath 
Tagore. It was a liberal periodical with a progressive outlook. It had also a corresponding Vernacular Publication called the Bangadoot printed in Bengali Persian and Hindi and was edited by Nilratan Haldar, a close associate of Ram Mohan. The Bengal Ankara the two leadings liberal English journals of the time in which Dwarkanath Tagore had large interests. Later Samuel Smith a leading book-seller and publisher of Calcutta purchased the Bengal Ankara, which happened to be one of the oldest and leading English papers in the early twenties of the nineteenth century. Under his editorship and guidance, the paper soon grew in popularity and usefulness. In the acquisition of this paper he was given substantial financial help by Dwarkanath Tagore. Dwarkanath was also one of the main proprietors of the India Gazette, another old and leading English newspaper at the time. The contribution of this newspaper towards the development of the progressive ideas in the country was, most significant and they acted as an ancillary to the Indian liberal press led by Ram Mohan. The progressive press was however, opposed by the unprogressive Samachar Chandrika and a similar Tory organ, John Bull. In spite of the vexatious opposition from the conservative and reactionary press, the cause of liberalism made steady program under the leadership of Ram Mohan and Dwarkanth Ultimately, John Bull had to be sold in 1832 to an enlightened and liberal minded journalist, J.H.Stocqueler again with a substantial aid from Dwarkanth . Another notable event that took place about this time was the establishment in 1831 of an English weekly in Calcutta named The Re former by the legal celebrity, peasant Coomar Tagore a cousin of Dwarkanath and a staunch follower of Ram Mohan. Its contribution to the cause of liberal and progressive-journalism in the country was considerable. This was soon followed by the other journals, The Inquirer in English and the Gyananweshan in Bengali and English. These were started by some enlightened young men of the Hindu college.

\section{Conclusion:-}

Even though the liberal and rational attitudes adopted by a section of the Indian Press were not generally interfered with in spite of the Regulation of Adam, Yet it was strongly urged before Lord Bentinck to repeal the Ordinance before he left for England. A petition to this effect, under the signature of Dwarkanath Tagore, William Adam and other was presented to Bentinck on February 6, 1835, and a favorable and sympathetic reply was received from the Governor- General. The next Governor-General Metcalfe adopted the same liberal attitude and eventually liberated the Indians Press from its fetters by rescinding the Regulation by passing his memorable Act 11 of 1835 . His action drew high acclamation in India while it was strongly criticized and resented by the Directors of the East India Company. It untimely led Metcalfe to relinquish his post. The next incumbent, however, did not in his wisdom, decide to repeal the Act. It was allowed to remain in force, since then, the Press had continued to remain more or less free in this country excepting for a short period during the movements of 1857-59. Thus the movement for the freedom of the Press, which was initiated by Ram Mohan on behalf of his countrymen, met with successful fruition not long after his death.

Ram Mohan's contribution as an indomitable defender of free Press in this country was grateful acknowledged by his contemporaries after his death. On the occasion of the free Press Dinner given in honor of Metcalfe, on February 9, 1838 in the Town Hall, Calcutta, Prasanna Coomar Tagore paid an eloquent tribute to the great contributions made by Ram Mohan for the freedom of the Press. The history of the Press in India is a history of struggle against autocratic power and popular spineless. That history has yet to be written. But when it comes to be written, the name of Ram Mohan, who shines out clearly in brilliant and honorable light amid the darkness of autocracy and indifferences would occupy a brilliant chapter in it. 


\section{References:-}

1. Sophia Dobson Collet, The Life and Letters of Raja Ram Mohan Roy, ed., Hemachandar Sarkar, Calcutta, 1913.

2. Ajit Kumar Ghosh, Rammohan Rachanavali, preface,p.40 as quoted in Reena Chatterji, Impact of Raja Rammohan Roy on the Society of India, New Delhi, S.Chand \& Co, 1983.

3. The Father of Modern India, Commemoration Volume of the Rammohan Roy Centenary Celebration, Calcutta, 1935.

4. Sivanath Shastri, The History of Brahmo Samaj, p.14 as quoted in S.N.Tagore, Makers of Indian Literature;Raja Ram Mohan Roy, Sahitya Academy, New Delhi, 1983.

5. S.N.Tagore, Makers of Indian Literature;Raja Ram Mohan Roy, Sahitya Academy, New Delhi, 1983.

6. Chaube, S.P., and Akhilesh Chaube, Educational Ideals of the Great in India, Neelkamal Publication, Hyderabad, 2002.

7. Das Gupta, B.N., The Life and Times of Raja Rammohan Roy, Ambika Publication, New Delhi, 1980.

8. Majumdar, R.C., Glimpses of Bengal in the Nineteenth Century, Calcutta, 1980.

9. Syed Nurullah and J.P.Naik, History of Education in India during the British Period ( Bombay: Macmillan \& Co.Ltd., 1943)

10. Vincent A.Smith, The Oxford History of India, ed. Percival Spear (3rd edn. Oxford: Clarendon Press, 1958.

11. Sen., A.K., Raja Rammohan Roy: The Representative Man, The Calcutta Textbook Society, Calcutta, 1967.

12. Mukherji, S.N., History of Education in India, Modern Period, Acharya Book Depot, Baroda, 1966. 